\title{
Competing Agendas and the Business of the American State Supreme Courts
}

\author{
Paul Brace1, Brent D. Boyea ${ }^{2}$ \\ ${ }^{1}$ Department of Political Science, Rice University, Houston, TX, USA \\ ${ }^{2}$ Department of Political Science, University of Texas at Arlington, Arlington, TX, USA \\ Email: pbrace@rice.edu, boyea@uta.edu
}

How to cite this paper: Brace, P., \& Boyea, B. D. (2019). Competing Agendas and the Business of the American State Supreme Courts. Beijing Law Review, 10, 971-991. https://doi.org/10.4236/blr.2019.104052

Received: July 30, 2019

Accepted: September 3, 2019

Published: September 6, 2019

Copyright (C) 2019 by author(s) and Scientific Research Publishing Inc. This work is licensed under the Creative Commons Attribution International License (CC BY 4.0).

http://creativecommons.org/licenses/by/4.0/ (c) (i) Open Access

\begin{abstract}
This project extends the research of Kagan et al. (1977) and Kritzer et al. (2007) to examine the production of cases in the American State Supreme Courts from 1995 to 1998 . We explore the relationship between the resources available to courts and litigation output to understand not only the relative efficiency of state courts, but the trade-off between areas of law (criminal, tort, and public law litigation). Due to the complex relationships between variable resources (inputs) and the competing demands of alternative areas of law (outputs), we utilize Data Envelopment Analysis (DEA) to estimate relative efficiency scores for overall case production and specific areas of law. Our findings suggest that while many state supreme courts are highly efficient, many operate below full efficiency. Moreover, activity in one area of law frequently comes at the expense of another area. In addition, we use Tobit analysis to evaluate the institutional, political, and social environmental influences that account for its variation. Whether courts are more or less efficient is attributable to the methods by which the American states staff their courts, the political preferences of judges, patterns of defendant success, the number of active attorneys, use of the death penalty, and the political ideology of a state's government.
\end{abstract}

\section{Keywords}

Public Law, Appellate Courts, Judicial Agendas, Data Envelopment Analysis, American State Courts

\section{Introduction}

\subsection{Structure of the Article}

The work of courts in the United States is not static. It changes to reflect politi- 
cal, social, and legal developments (see Munger, 1990). Past research has described the different foci of the American courts at the federal and state levels in trial and appellate courts (see e.g., Kagan et al., 1977; Daniels, 2006; Habel \& Scott, 2014; McIntosh, 1980-1981; Stookey, 1990; Pacelle, 1991, 1995). Of particular interest for our analysis of state supreme courts, those that operate at the highest level of the American state judiciaries are the work of Kagan and his colleagues. Kagan et al. (1977) traced the changing dockets of a sample of 16 states over the period from 1870 to 1970 . They took samples of 18 cases decided by each of the 16 courts every fifth year (i.e., 1870, 1875, 1890, etc.) Their analysis shows a decided shift in the dockets of these 16 courts. Aggregating their data into three time periods (1870-1900, 1905-1935, and 1940-1970), they found a steep decline in the percentage of cases involving business issues (contracts, debt, corporations, and partnerships) and real property; these two areas were supplanted by increases in tort, criminal, public law, and family and estates cases. In the latest periods examined by Kagan and his colleagues, criminal cases comprised 18 percent of the state supreme court dockets they examined, and torts comprised 22 percent. Given the tort and criminal rights revolutions observed from 1940-1970, one would expect these shares to have grown significantly. In an update of the Kagan study, Kritzer et al. (2007) show that many of the patterns described by Kagan et al. continued through the 20th century: debt and real property litigation continued to decline, and criminal appeals continued to increase. In sum, over a period of over 100 years, past research has described a transformation of state supreme court dockets with increasing attention to criminal and tort cases and a decline in other areas of appeal.

The "long view" provided by this research tradition is invaluable because it describes major features of the work of the American state courts in the aggregate which allows us to better understand their functions within the judicial system. This research is not the final word on the work of state supreme courts, however. These studies provide careful and important descriptions of patterns in state supreme courts, but do not unravel the trade-offs between these foci in shaping the activities of these courts. As noted by Kritzer at al. (2007): "Research designs with cross-sectional and temporal variation seem essential for gauging the effects of endogenous and exogenous trends on the ways courts operate and serve society" (p. 437).

\subsection{Research Objective}

Our goal in this study is to delve more deeply into the decisional outputs of state supreme courts from a comparative, cross-sectional perspective. As we shall illustrate, state supreme courts exhibit substantial variety in the total decisions they issue in the major areas of adjudication: criminal, tort, and public law. Our interest is in why some states produce more cases given their resources than others, and the forces that shape this variability. Following the research tradition interested in the work of these courts, we focus on the comparative quantity of 
these cases across courts and leave the evaluation of the "quality" of these decisions to future research.

To guide our study, we extend the apt title of Kagan et al.'s (1977) pioneering study "The Business of State Supreme Courts" and treat these bodies like business decision-making units that produce outputs (cases) with inputs. Our interest is inefficiency, or how some states produce more with given inputs than others. We make no claim as to the normative value of such efficiency: clearly some states may produce more because their decisions are hasty, while others produce less because their decisions are more thoughtful. The comparative efficiency of state supreme courts, however, does provide a means to better judge the observed work of state courts beyond simply looking at the raw number of their decisions. It allows us to compare systematically how the decisional outputs of courts vary overall, and within areas of law, controlling for the conflicting demands of alternative cases and variations in productive resources. As will be shown, some states produce more cases overall or more cases within different areas of law, given their resources compared to others. As such, they more efficiently convert court resources into case outputs. This variation, in turn, is subject to evaluation, asking what political and social demographic forces help account for these variations inefficiency. In sum, we seek to understand the business of state courts by treating them in some ways analogous to a business, and use well-developed tools of productivity analysis to gauge their comparative productivity and the forces that shape their performance.

We employ Data Envelopment Analysis (DEA) (Aigner \& Chu, 1968) to estimate the comparative productivity of these courts based upon variable resources. As described below, this technique allows us to estimate an efficient production frontier derived from the observed comparative performance of these courts across the major areas of law controlling for their variable endowments of resources and the competing demands of the alternative areas of law. From this we can gauge the overall efficiency of the courts and illustrate which state supreme courts are at or below the efficient frontiers across areas of law. These measures of comparative state supreme court productivity will reveal striking differences overall and within areas of law. To account for these variations, we subject these measures to multivariate analyses employing an array of institutional, political and social explanatory influences.

\section{Mapping the Productivity of State Supreme Courts}

The data for this analysis are taken from the Brace-Hall State Supreme Court project. This comprises all decisions of the American state supreme courts from 1995 to 1998. Because Texas and Oklahoma each have two state supreme courts that divide criminal from civil cases, we exclude them from the analysis and focus on the remaining 48 states where their courts must balance between demands for criminal and civil litigation. Because our interest is in cross sectional differences, we focus on the average outputs of these courts over the four years 
of data in criminal, tort, and public law litigation. Appendix A defines the relevant variables used throughout this analysis.

As can be seen in Figures 1-4, state supreme courts exhibit striking variability in their decisional outputs, which is averaged by the four years of available data. While the Brace-Hall State Supreme Data project restricts total yearly observations to 200 observations using random samples, Figure 1 demonstrates that five states, including the high courts of Arkansas, Florida, and Maine, heard at least 200 cases per year. Several other courts, including those in Alabama, Mississippi, Georgia, and West Virginia, heard just under 200 cases per year. As for the least active court, the Arizona Supreme Court settled just 55 cases per year, on average. Relating to the separate policy areas, similar variation is evident. Within the area of criminal litigation, Figure 2 shows that no court surpassed the criminal case activity of the Florida Supreme Court, which heard approximately $98 \mathrm{crim}$ inal cases per year. At the opposite end of the criminal spectrum is the Alaska Supreme Court, which heard about 4 criminal cases per year. According to the illustration of tort litigation in Figure 3, Alabama heard an average of 78 cases per year, well ahead of any other state. Oppositely, several courts including the high court of Arizona largely ignored tort disputes. Of the courts dealing with

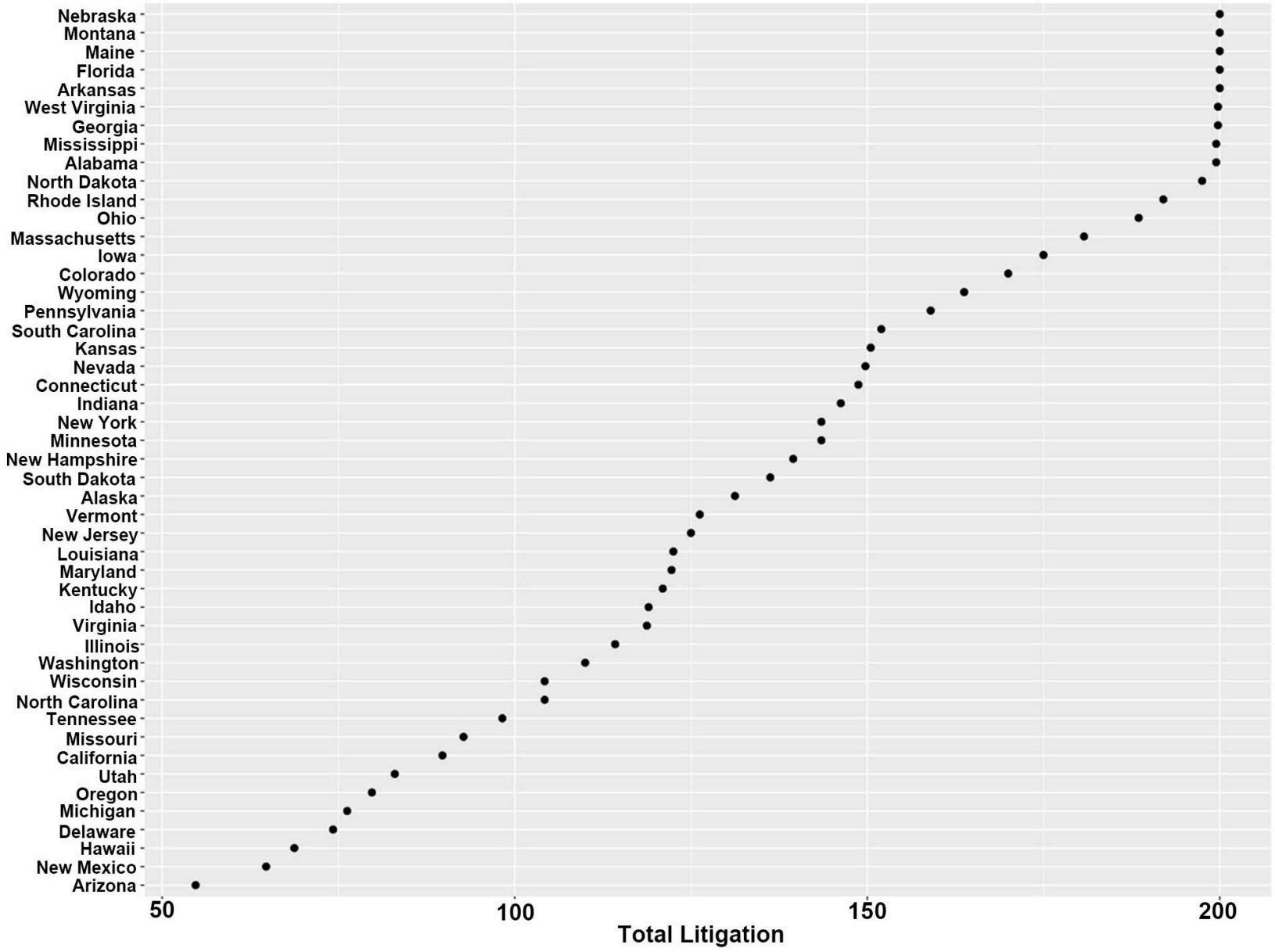

Figure 1. Mean litigation by state. 


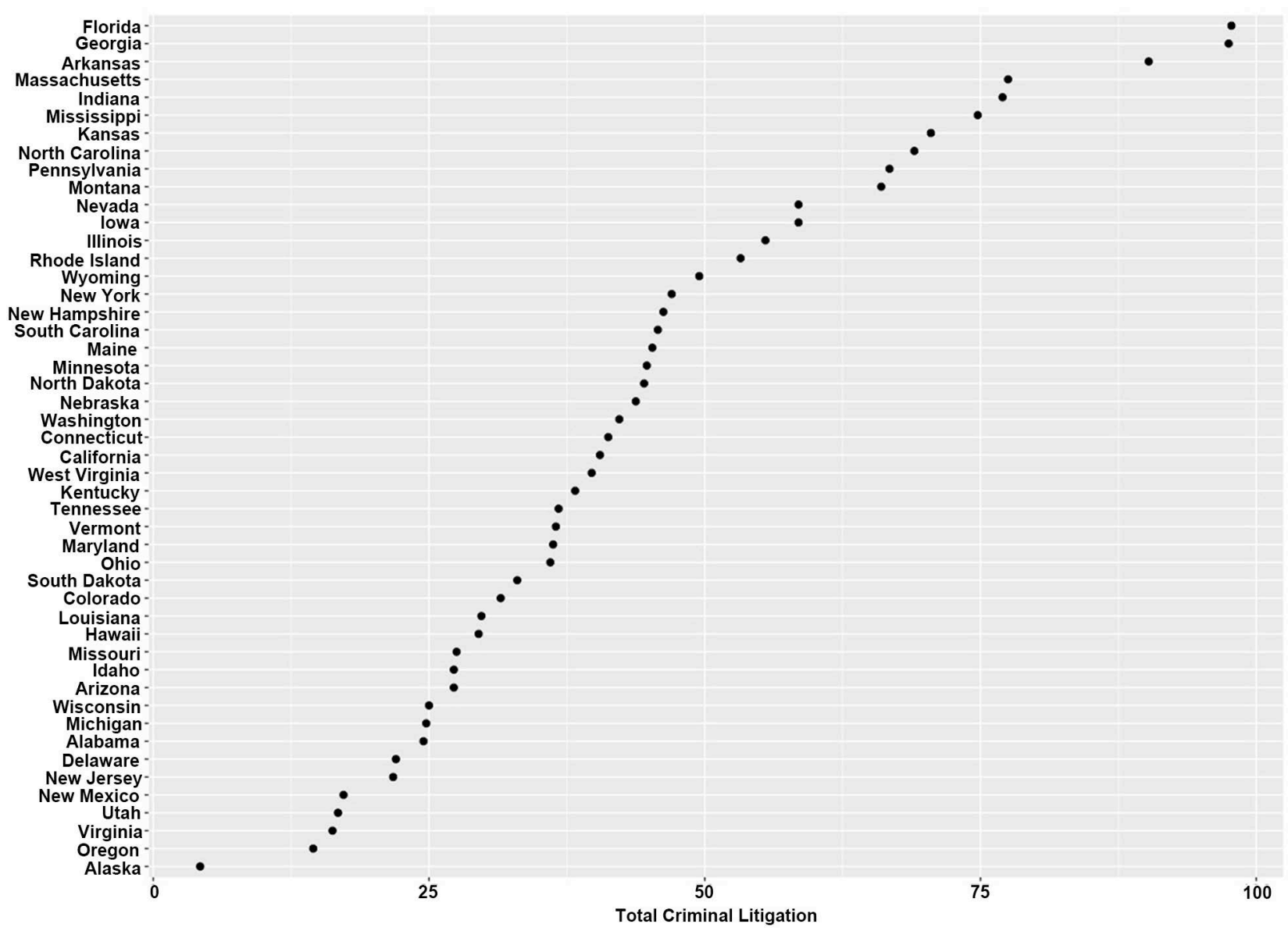

Figure 2. Mean criminal litigation by state.

public law litigation, Figure 4 shows that variation was typical, following the patterns observed for criminal and tort litigation. The most active court in the area of public law was the Ohio Supreme Court, which heard approximately 114 public law cases per year. The least active court was the Delaware Supreme Court, which settled just 12 public law cases per year.

Such descriptive evidence concerning the three most routine areas of law suggests that courts have varying inclinations toward specific areas of law. For example, while the Alabama Supreme Court specializes in tort litigation, Indiana's court largely avoids torts and directs most of its attention to criminal appeals. Similar statements can be made about courts that specialize and avoid both criminal and public law litigation. The remainder of this paper will explore the different state supreme courts to determine the performance of those courts, or whether state supreme courts produce the quantity of cases expected per area of law.

\section{The Efficiency of State Supreme Courts}

While state supreme courts exhibit wide variation in their total decisions, and in the different areas of law, these differences do not provide much leverage for 


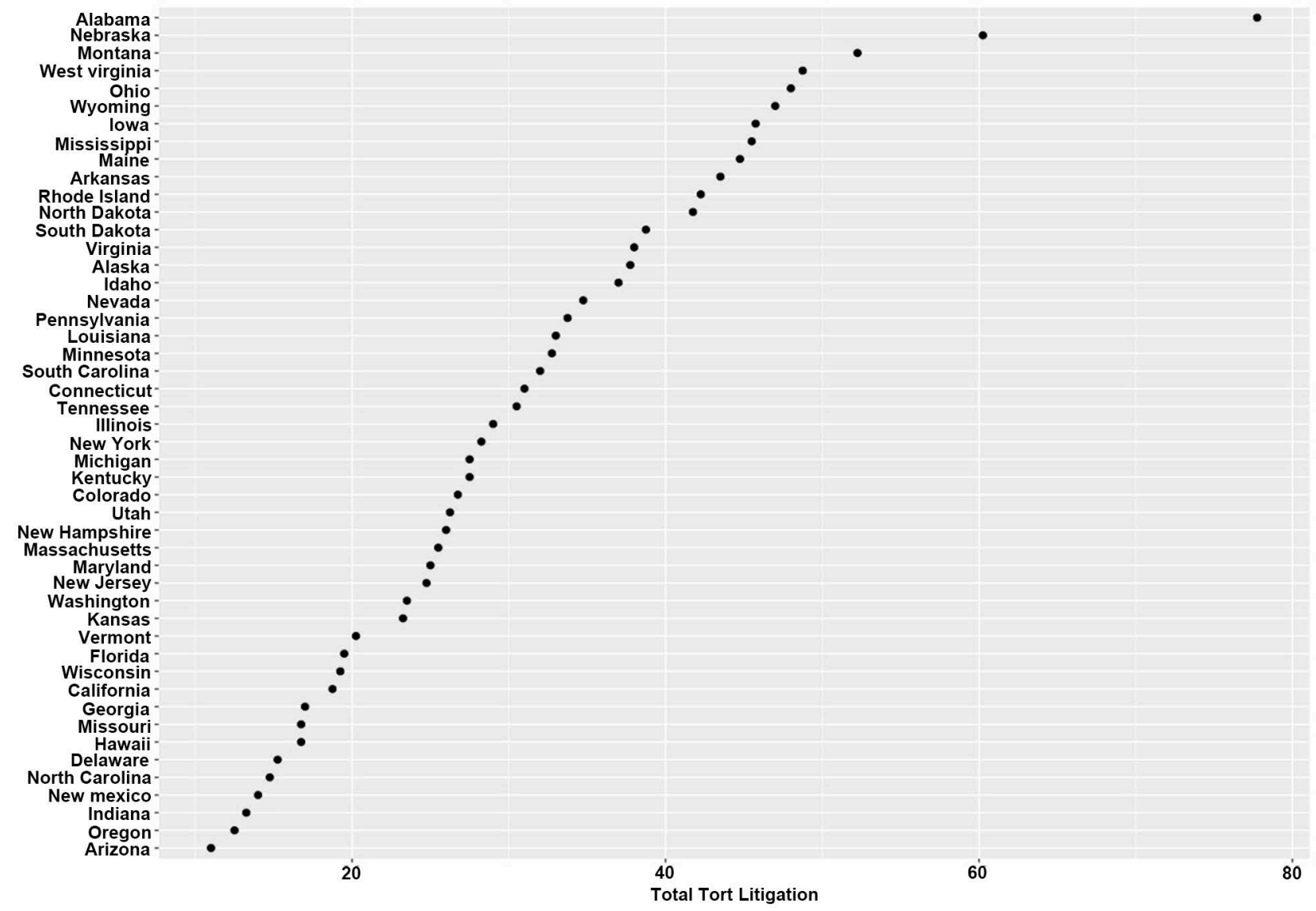

Figure 3. Mean tort litigation by state.

assessing how state high courts perform their functions. The reason is state supreme courts vary in the resources they bring to their task. Fortunately, to produce the measure of performance, DEA permits the inclusion of multiple input and output variables. Output variables used to calculate efficiency include measures of court activity which are expressed as the number of cases litigated in the areas of criminal, tort, and public law. Inputs within the analysis of performance include a variety of legal and structural variables that affect the performance of courts. With each of these variables, the court system for each state has no direct effect on the input influence.

One input variable used in this analysis controls for the policy content of state constitutions. With state constitutions applying unique state rules, customs, and civil rights, state supreme courts act as the final arbiters of their state constitutions and these constitutions vary dramatically in their policy content (Dinan, 2018; Hammons, 1999). Longer, more policy-based constitutions, in particular, give state supreme court decisions increased discretion when making decisions (Brown, 2018). Where state constitutions are expansive and cover many policy areas, both litigants and justices have more resources to develop cases. Conversely, where state constitutions are short and framework oriented, litigants have fewer grounds for appeal and judges have fewer constitutional resources for adjudicating. 


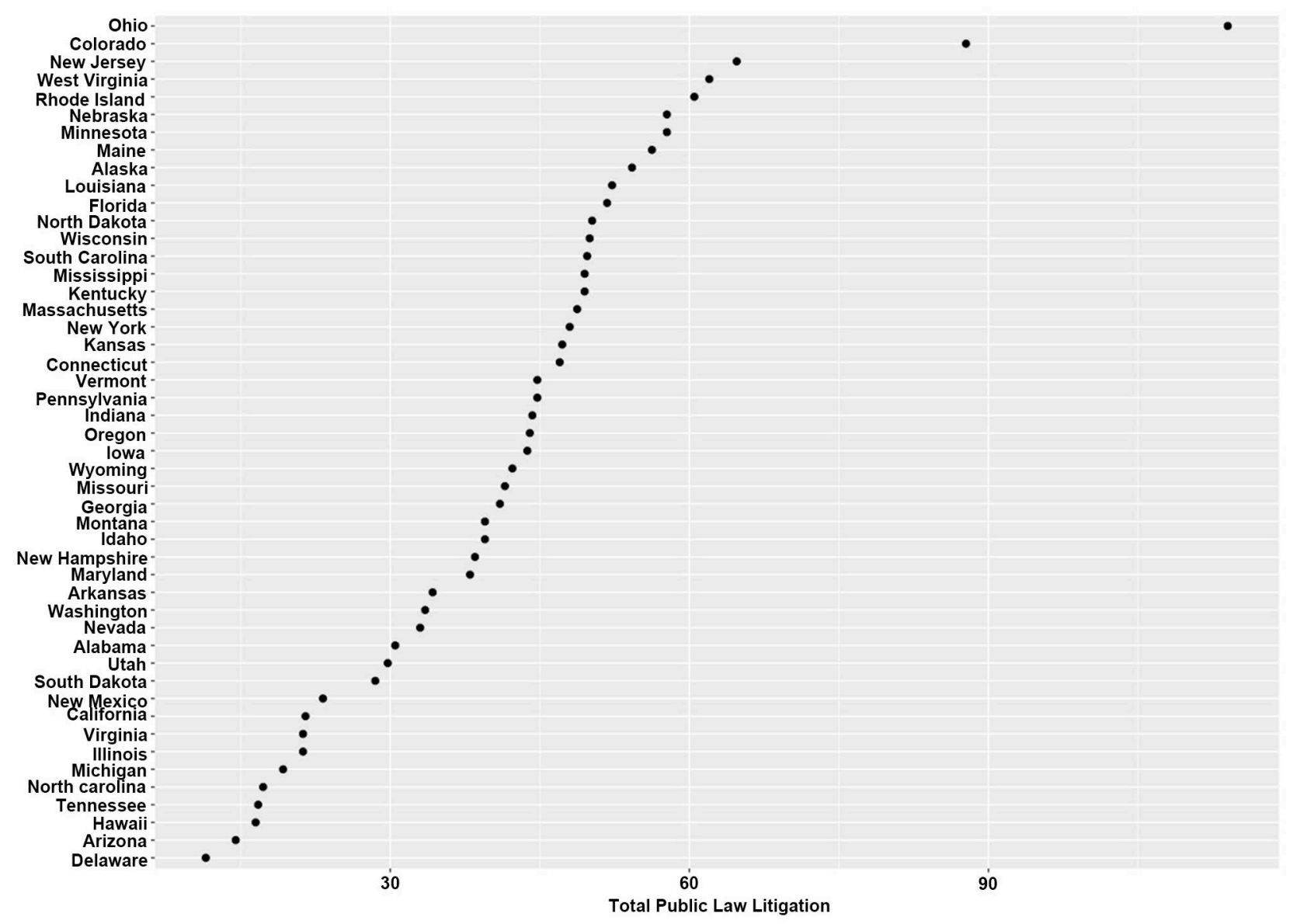

Figure 4. Mean public law litigation by state.

Another input variable relates to the structure of state supreme courts. Throughout the states, state supreme courts vary in composition from five to nine judges. We anticipate that courts with more members can share the burden of decision writing more broadly. The resources of courts also affect the performance of courts. Squire (2008) and Brace and Hall (2001) demonstrate that state supreme courts vary in their level of professionalization, which includes components connected to staff size, operating budgets, research assistance, and judicial salaries. We control for this variation using Squire's (2008) docket-controlled measure of professionalism. We expect that courts with abundant resources will have greater capacity to settle higher sums of cases. Finally, the tiered structure of state court systems is notably different. Most state court systems have intermediate appellate courts which generally afford state supreme courts the discretion to hear or not hear an appeal. The remaining states have no such intermediate appellate courts, and their state supreme courts process nearly all appeals. We expect that states with lower appellate courts will decrease the burdens of state high courts.

The differences in the policy content of state constitutions, state supreme court size, the professionalism of state supreme courts, and the structure of their appellate system are illustrated in Table 1 . The descriptive statistics reported in 
Table 1. Characteristics of input variables.

\begin{tabular}{|c|c|c|c|c|}
\hline State & $\begin{array}{l}\text { Constitutional } \\
\text { Policy Content }\end{array}$ & Size of Court & $\begin{array}{c}\text { Professionalism } \\
\text { Score }\end{array}$ & Appellate Court \\
\hline Alabama & 5204 & 9 & 0.513 & Yes \\
\hline Alaska & 723 & 5 & 0.69 & Yes \\
\hline Arizona & 1007 & 5 & 0.598 & Yes \\
\hline Arkansas & 1550 & 7 & 0.506 & Yes \\
\hline California & 1263 & 7 & 1.004 & Yes \\
\hline Colorado & 1168 & 7 & 0.485 & Yes \\
\hline Connecticut & 393 & 7 & 0.571 & Yes \\
\hline Delaware & 558 & 5 & 0.618 & No \\
\hline Florida & 793 & 7 & 0.707 & Yes \\
\hline Georgia & 960 & 7 & 0.644 & Yes \\
\hline Hawaii & 549 & 5 & 0.532 & Yes \\
\hline Idaho & 640 & 5 & 0.512 & Yes \\
\hline Illinois & 538 & 7 & 0.69 & Yes \\
\hline Indiana & 390 & 5 & 0.578 & Yes \\
\hline Iowa & 328 & 9 & 0.46 & Yes \\
\hline Kansas & 439 & 7 & 0.477 & Yes \\
\hline Kentucky & 697 & 7 & 0.621 & Yes \\
\hline Louisiana & 1537 & 7 & 0.667 & Yes \\
\hline Maine & 361 & 7 & 0.406 & No \\
\hline Maryland & 937 & 7 & 0.513 & Yes \\
\hline Massachusetts & 836 & 7 & 0.575 & Yes \\
\hline Michigan & 770 & 7 & 0.878 & Yes \\
\hline Minnesota & 353 & 7 & 0.586 & Yes \\
\hline Mississippi & 619 & 9 & 0.36 & Yes \\
\hline Missouri & 1313 & 7 & 0.64 & Yes \\
\hline Montana & 443 & 7 & 0.473 & No \\
\hline Nebraska & 623 & 7 & 0.562 & Yes \\
\hline Nevada & 588 & 5 & 0.407 & No \\
\hline New Hampshire & 335 & 5 & 0.694 & No \\
\hline New Jersey & 453 & 7 & 0.712 & Yes \\
\hline New Mexico & 838 & 5 & 0.466 & Yes \\
\hline New York & 1093 & 7 & 0.724 & Yes \\
\hline North Carolina & 410 & 7 & 0.548 & Yes \\
\hline North Dakota & 565 & 5 & 0.253 & No \\
\hline Ohio & 1012 & 7 & 0.601 & Yes \\
\hline Oregon & 758 & 7 & 0.526 & Yes \\
\hline
\end{tabular}




\begin{tabular}{ccccc} 
Continued & & & & \\
\hline Pennsylvania & 670 & 7 & 0.876 & Yes \\
Rhode Island & 282 & 5 & 0.53 & No \\
South Carolina & 721 & 5 & 0.728 & Yes \\
South Dakota & 601 & 5 & 0.336 & No \\
Tennessee & 391 & 5 & 0.717 & Yes \\
Utah & 500 & 5 & 0.329 & Yes \\
Vermont & 233 & 5 & 0.352 & No \\
Virginia & 579 & 7 & 0.661 & Yes \\
Washington & 1232 & 9 & 0.64 & Yes \\
West Virginia & 725 & 5 & 0.813 & No \\
Wisconsin & 405 & 7 & 0.629 & Yes \\
Wyoming & 576 & 5 & 0.394 & No \\
\hline
\end{tabular}

Table 1 demonstrates that states and their state supreme courts vary widely in the resources they bring to bear on producing judicial decisions. These descriptive statistics suggest that as input, these four features of American state government and state supreme courts determine whether courts are either efficient in terms of maximum case production or less efficient in relation to hearing fewer cases than expected. Where state constitutions, the size of courts, resources devoted to courts, and the presence of intermediate appellate courts vary, courts either operate at full production or something below full efficiency.

\section{Methodology}

Our interest in analyzing three outputs and four resource inputs presents a complex problem. Case outputs of state courts in particular areas of law are correlated with the input resources described above, but they are also correlated with case outputs in the other areas of law. The joint correlations of specific outputs with inputs and other outputs range from 0.42 to 0.65 . Obvious problems with simultaneity make use of regression variants such as 3SLS impractical because of difficulties identifying unique and convincing instrumental variables for each area of law.

Fortunately, DEA (Aigner \& Chu, 1968; Varian, 1984) was developed specifically for analyzing the production of multiple outputs by decision-making units (in our case courts) as a function of multiple inputs. DEA employs linear programming to construct a non-parametric piece-wise surface (the frontier) based upon observed inputs and outputs. The efficiency measure theta is calculated relative to this surface and is equal to one for those units producing the most output for given inputs, and less than one for units that produce comparatively less. These efficiency scores allow us to compare the case productivity of state courts given their resources. Moreover, these scores allow us to estimate the efficient frontier levels of output for each court, which in turn can be compared 
with the observed levels of output for that same court.

More formally, we have $\mathrm{N}$ inputs (size, policy content of state constitution, professionalism, lower appellate court) and $\mathrm{M}$ outputs (criminal, tort, public law litigation) for each of I courts. For the th court these are represented by a column vector $x i$ and $q i$ respectively. The $\mathrm{N} \mathrm{x}$ I input matrix, $\mathrm{X}$, and the $\mathrm{M} \mathrm{x}$ I output matrix, $Q$, represents the data for all I firms. For each firm we obtain a measure of the ratio of all outputs over all inputs $u^{\prime} q^{i}{ }^{\prime} v^{\prime} x i$, where $\mathrm{u}$ is a matrix of $\mathrm{M} \mathrm{x} \mathrm{I} \mathrm{vector} \mathrm{of} \mathrm{output} \mathrm{weights} \mathrm{and} v$ is a $\mathrm{N} \mathrm{x} \mathrm{I} \mathrm{vector} \mathrm{of} \mathrm{input} \mathrm{weights.} \mathrm{DEA} \mathrm{ob-}$ tains the optimal weights by solving the following mathematical programming problem:

$$
\begin{aligned}
& \text { Max } u, v\left(u^{\prime} q i\right), \\
& \text { st } \quad v^{\prime} x i=1, \\
& u^{\prime} q i-v^{\prime} x i<0, j=1,2, \cdots, I, \\
& u, v>0 .
\end{aligned}
$$

DEA does this by finding values for $u$ and $v$, such that the efficiency measure for the ith firm is maximized subject to the constraints that all efficiency measures must be less than or equal to one. The linear programming problem is solved I times for each court, producing a value of theta, which is a composite overall efficiency score for each court which ranges from zero to one. Courts scoring one are at the efficiency frontier relative to other courts, while courts scoring less than one are operating at a proportion of total efficiency (e.g., a score of 0.40 means a court is operating at $40 \%$ efficiency). In addition to the composite measure of efficiency and the corresponding ranks of courts, DEA provides an estimate of output slack for each output (in this case decisions in alternative areas of law). Slack for a given output represents the amount below the efficient output a given court produces in a particular area of law and is equal to zero if a court is at the efficiency frontier.

Taken together, DEA provides a systematic method for estimating the relative total efficiency of courts (theta), their rank, and the shortfall in outputs relative to the efficient level of output in specific areas of law. From this, we can illustrate the overall comparative productivity of state supreme courts, given their inputs, as well as their comparative productivity within specific areas of law.

\section{Estimating State Supreme Court Efficiency}

The data analyzed include the agendas of forty-eight American state supreme courts from 1995 to 1998, with the exception of the high courts of Oklahoma and Texas. We begin by using DEA on the inputs for the policy content of state constitutions, state supreme court size, professionalism, and structure of state appellate systems on the three outputs of criminal, tort and public law cases. Each figure is ordered by state rank of relative efficiency.

Figure 5 demonstrates that efficiency scores vary from 1 (AL, AR, GA, IN, IA, KS, ME, MS, MT, NV, ND, OH, RI, VT, WV and WY) to 0.369 (NM). For state supreme courts with a value of 1 for efficiency, those courts operate at total 


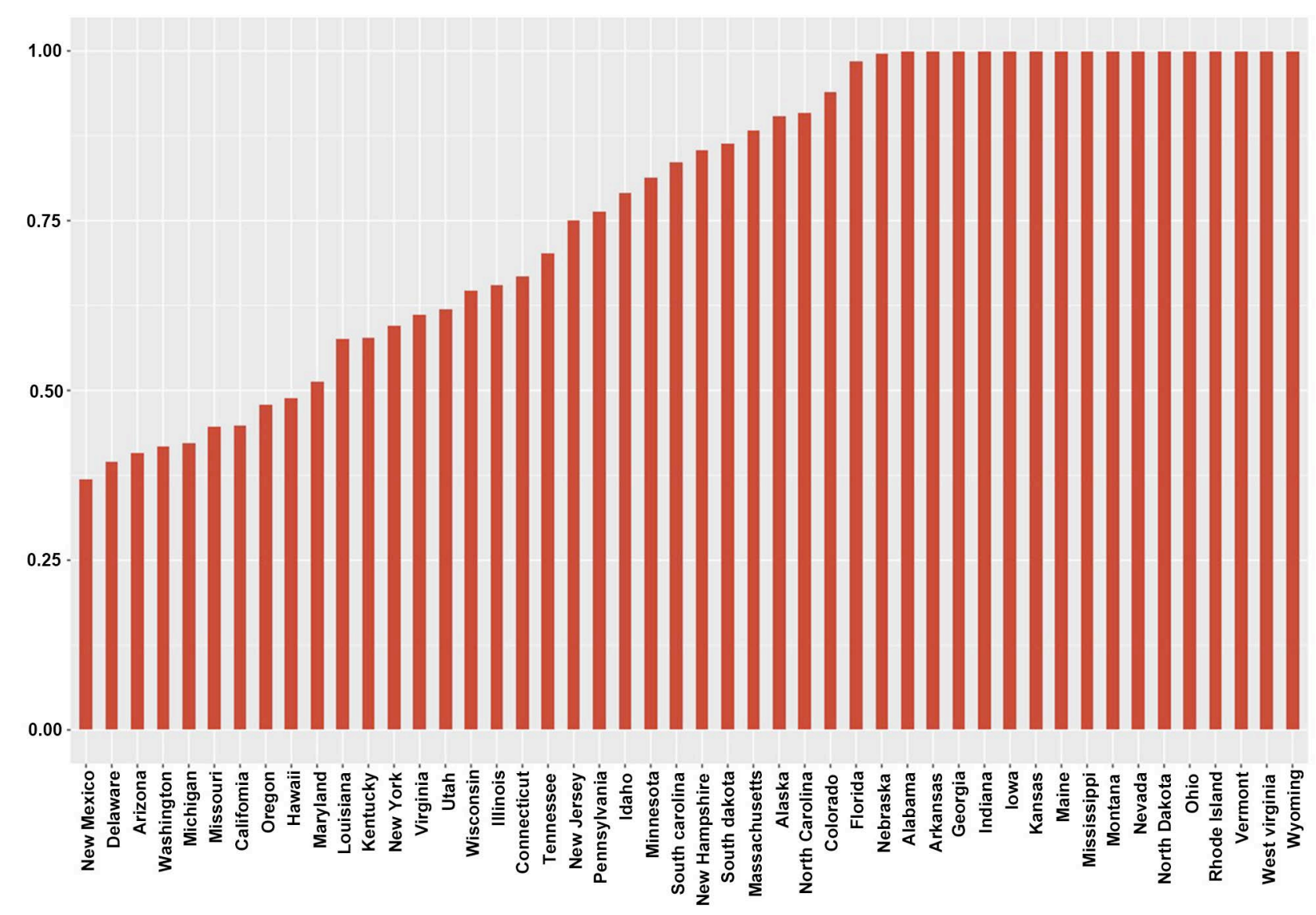

Figure 5. Caseload efficiency.

relative efficiency. For New Mexico, the least efficient court, the efficiency score indicates that the court produced just 36.9 percent of the cases one might expect given its resources when compared to the most efficient states. The remaining states lie between these two extremes.

We use the efficiency scores to estimate the efficient frontier of case productivity, $((1-$ theta $)+1)$ multiplied by observed cases, and compare this with observed case output. This comparison is illustrated in Figure 6. Efficient courts are on the frontier, while less efficient courts fall below. The efficient state courts in terms of overall case production reside at the productive frontier: their observed output equals the estimate of efficient output. The less efficient supreme courts fall below the frontier.

Examination of Figure 6 makes clear that efficient and inefficient states are distributed quite broadly across levels of state court case output. Courts from both small and very large states are found among the comparatively inefficient. If there is a pattern, it appears that states at the lower end of case output, like Arizona, Delaware, Hawaii, and New Mexico, are also collectively inefficient. No court in this lower range achieves efficiency. Clearly there are floor levels in our input variables. Even at the lower levels of case output, these states have at least five justices, constitutions with non-negligible policy content, at least a base level 


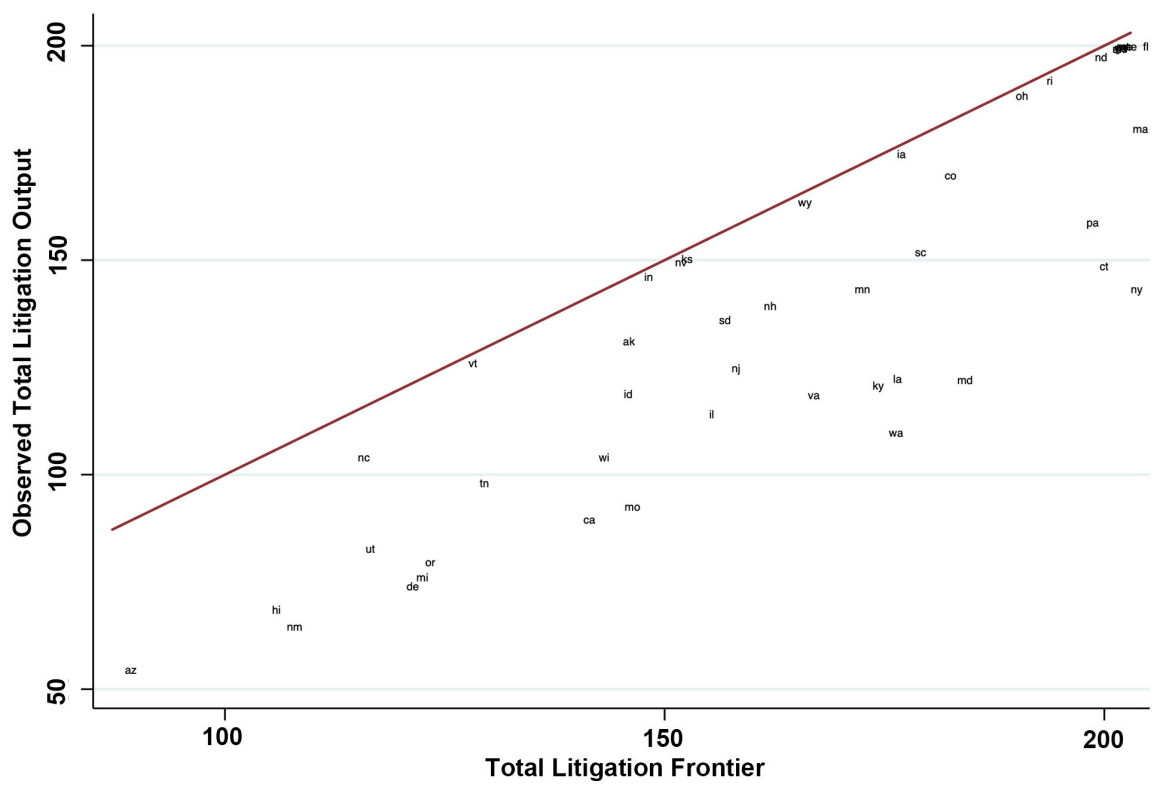

Figure 6. Total litigation efficiency.

of professionalization, and may have lower appellate courts. This pattern indicates these levels of output could have been produced with reduced levels of inputs, but norms of court size, operations, structure and constitutions provide them with more resources then they need for the number of cases produced. This does not mean that observed output levels equate to efficiency levels. As noted above, there are many states with comparable levels of output but widely varying levels of efficiency. In these cases, inefficient courts could clearly produce more given their resources. For example, New York produces fewer cases than Ohio. However, the results indicate it could have produced approximately 58 more cases given its resources, while Ohio produced as much as could be expected with theirs. The business of state supreme courts is not simply a matter of their output: some courts operated at the limits of their resources, while others were at their limits.

The relative efficiencies of state supreme courts within specific areas of law are illustrated in Figure 7 through 9. Beginning with criminal cases in Figure 7, efficient levels of output in criminal cases are evident for the least (NM) and most (FL, GA) productive courts. Given the inefficiencies observed in total court output, this suggests that efficiencies in one area of law may be achieved at the expense of other areas of law. This pattern will become clearer as we examine alternative areas of law. The most notably inefficient states in criminal cases (in order) are Alaska, Alabama, Virginia, New Jersey, and Utah. In comparison to other states with similar levels of output they could have produced substantially more criminal cases than were observed.

Figure 8 presents comparable results for tort cases. Most notably, Alabama produced the most tort appeals by far and, in this case, did so efficiently. Contrast this with Alabama's processing of criminal cases where there was a shortfall 


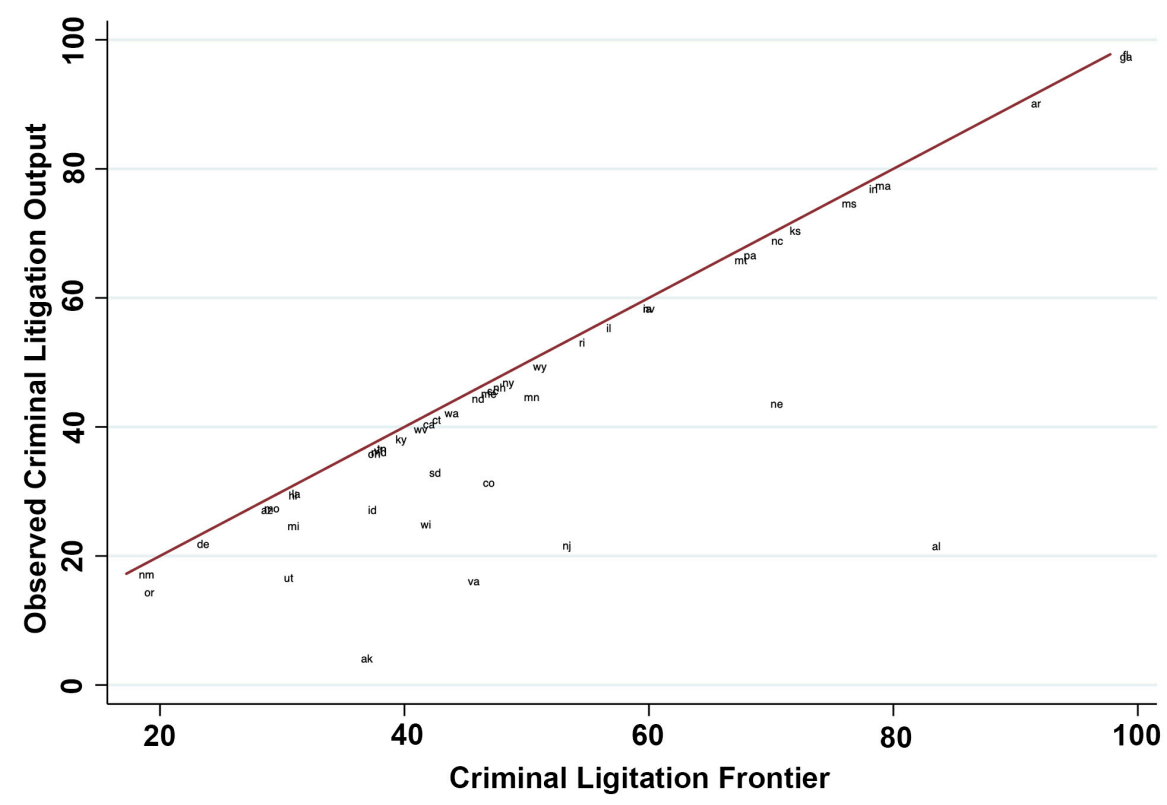

Figure 7. Criminal litigation efficiency.

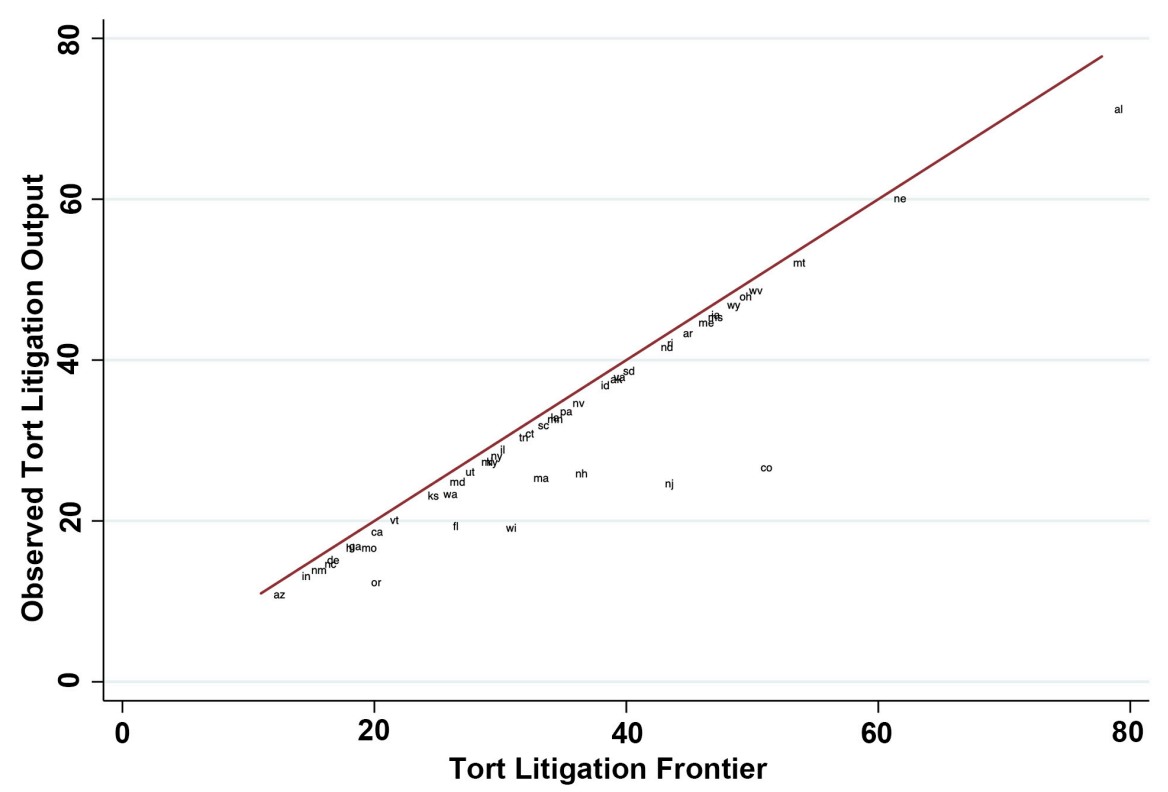

Figure 8. Tort litigation efficiency.

in output. The Alabama Supreme Court produced the maximum number of tort cases given its resources, while it produced far fewer criminal cases than it could have given the resources available to the court. The most inefficient state high courts in the area of tort law were those in Colorado, New Jersey, Wisconsin, and Oregon. For those courts, the number of cases produced aligned poorly with the resources granted those courts.

Figure 9 presents the results concerning public law cases. While most states were highly efficient with the production of their public law cases, Alabama again exhibits a notable pattern. As it was in criminal law cases, it was the most 


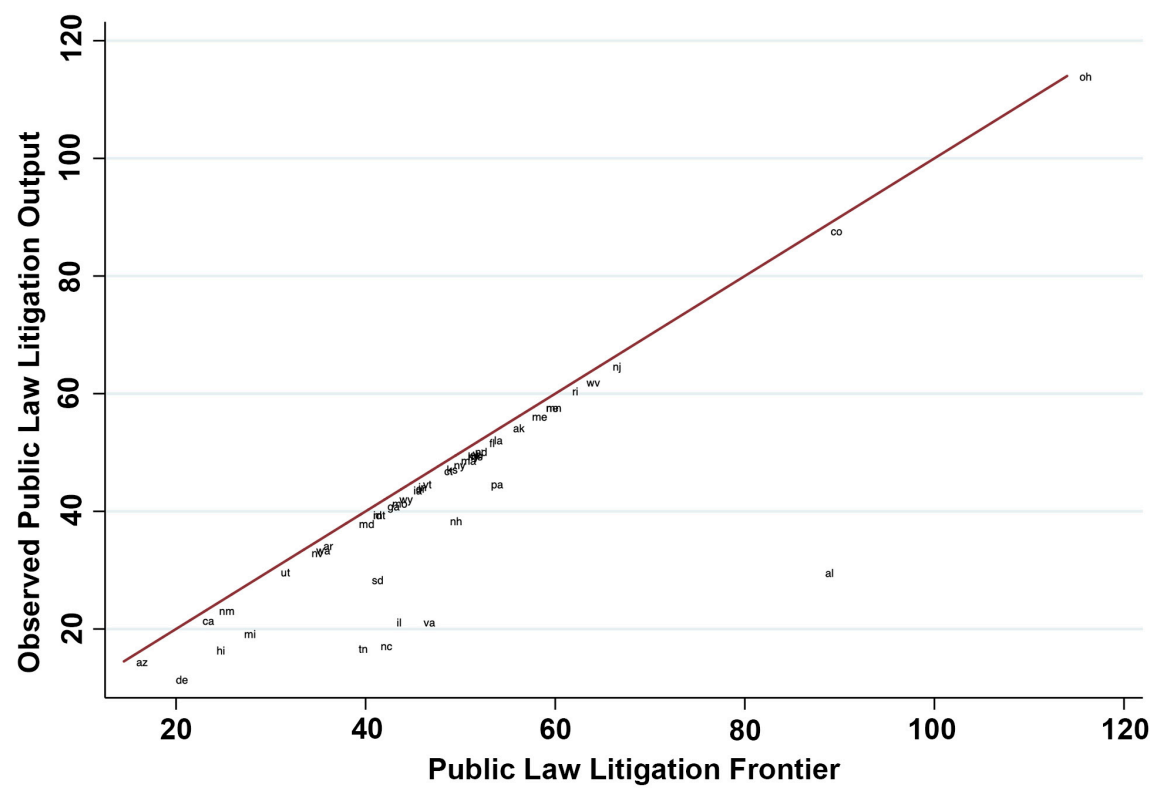

Figure 9. Public law litigation efficiency.

inefficient court in producing public law cases as well. It seems clear that the efficiency it devotes to produce record levels of tort cases comes at the expense of its ability to process criminal and public law cases. Following Alabama, North Carolina, Tennessee, and Virginia all produced far fewer cases than one might expect. Otherwise, a majority of courts produced efficient loads of cases in the area of public law.

Comparing state supreme court efficiencies by area of policy, we see unique patterns. New Hampshire, Florida, and Massachusetts were highly efficient courts with their criminal cases, yet mildly inefficient with tort cases. Alaska, Alabama, Virginia, and Utah, on the other hand, were efficient with tort law cases, but did not produce the number of criminal cases one might. New Jersey, Colorado, and, to a lesser extent, Oregon and Wisconsin, were efficient with neither tort nor criminal law. The remaining states were at or near efficient levels of case output for both areas of law.

When comparing criminal and public law cases, North Carolina, Tennessee, Illinois, and Delaware were efficient with criminal law cases, yet under-produced with their public law docket. By contrast, Alaska and New Jersey operated at full efficiency with their public law cases, yet there was a shortfall in output in the number of criminal cases. Alabama and Virginia were very inefficient with both criminal and public law cases; otherwise, most states produced efficient outcomes for both policies.

Comparing tort and public law decisions, Alabama, Tennessee, Virginia, and Illinois were efficient with tort appeals, but less effective in producing public law decisions. Colorado, New Jersey, Wisconsin, and Oregon produced an efficient number of public law cases, but were moderately inefficient with tort cases. Two states-New Hampshire and North Carolina-were inefficient with both the tort and public law outputs. The remaining courts were at or very near the efficient 
level of case production across all three areas of law.

Several states were efficient across two areas of policy, yet weak within a third area. Tennessee, Illinois, and Delaware were efficient with their criminal and tort cases, yet produced far fewer public law cases than might be expected. Florida and Massachusetts exhibited mild inefficiency in the area of tort law, while they were efficient in criminal and public law cases. Similarly, the high courts of Alaska, Idaho, Minnesota, and Louisiana were strong producers of tort and public law cases, yet were ineffective with their criminal law outputs.

The results presented in Figure 6 through 9 present a puzzle, but it is a puzzle that is revealing. Clearly, states vary widely in the numbers of cases they produce. There are also pronounced differences in court efficiency in overall output and within areas of law. Many states produce cases in each area of law at efficient levels, indicating that they are at the observed productive limits of their resources. Alternatively, several states are consistently inefficient, producing fewer cases than they could overall and within areas of law. Finally, some states are efficient in one or two areas of law while inefficient in others. While these various patterns appear puzzling, they underscore a very fundamental point: there are striking differences in the "business" of state courts. While they produce different levels of case outputs, it is also evident that they make differential use of their resources in doing so.

As noted above, we do not wish to impart a normative dimension to this measure of efficiency. Efficiency as measured is based on the comparative analysis of raw case outputs given basic court resources. In this initial exploration, we have not attempted to delve into the dimensions of the quality or seriousness of court case outputs, a topic very worthy of future consideration using these methods. At first glance, however, this initial exploration reveals very notable differences between state supreme courts in how they employ their resources to produce cases. An obvious question concerns what forces might account for these differences, a topic we turn to below.

\section{Explaining State Supreme Court Efficiency}

\subsection{Model of State Supreme Court Efficiency}

What might account for differing levels of state supreme court efficiency? In this section, we treat the measure of overall court efficiency and model it as a function of institutional, political and social variables that account for this variation. The efficiency measure takes on values between 0 and 1 and is thus censored, necessitating the use of Tobit analysis which is otherwise quite comparable to OLS regression in results.

Institutionally, state supreme courts are distinguished by how their members are selected. American states courts, unlike most courts throughout the world, sometimes elect their judges through public elections, rather than selection by elite appointments. During the period of this analysis, twenty-two states out of fifty elected their state supreme court justices. Our ELECTIVE COURT variable 
equals one for elective courts staffed by judicial elections, and zero for non-elective courts. Because elected judges must navigate through the public scrutiny of their decisions, we expect elective courts to be less efficient. Justices on state supreme courts also differ in their ideologies. The liberalism or conservatism of a court, per se, would not be obviously related to their court's outputs. Indeed, very liberal or conservative courts would send signals to potential appellants about likely outcomes. Faced with a conservative (liberal) court, conservative (liberal) litigants would have liberal (conservative) adversaries more willing to settle out of court to avoid additional expenses and a likely adverse outcome (Brace, Yates, \& Boyea, 2012). Alternatively, courts with justices with a wide range of ideologies would create uncertainty among litigants. Courts with a wider array of ideologies could thus attract a wider range of appeals than courts with greater ideological homogeneity. We employ the pajid measure of state supreme court ideology (Brace, Langer, \& Hall, 2000) to construct PAJID RANGE, the difference in ideology between the most and least conservative justice on a state supreme court.

We employ four measures of the legal environments of the courts. QTY DEF WINS $(t-1)$ captures the number of cases won on appeal in a state supreme court in the preceding year. Higher levels of this variable indicate a court willing to reverse lower court decisions, which could indicate judicial activism, or the need for error correction, or both. It also sends signals to potential appellants that the court could provide relief. In all regards, we expect this variable to be related to higher levels of court efficiency. We consider the demand for adjudication by including CASE FILINGS(t-1). Our expectation is that where case filings are higher, state supreme courts will have greater incentives to operate efficiently. We also expect the availability of legal counsel to influence court efficiency. When legal resources are scarce, we believe more reversible errors are likely to occur in lower courts, producing a stronger justification for appeal and thus placing more pressure on state supreme courts to operate efficiently. Consequently, we expect LAWYERS PER CAPITA to be inversely related to state supreme court efficiency because more abundant legal resources can reduce the volume of appeals, and make the appeals that do proceed more complex. Our final measure of the legal environment of state supreme courts concerns whether it operates in a DEATH PENALTY state. From 1995 through 1998, thirty-eight states used the death penalty for capital crimes. Following the U.S. Supreme Court's decision in Gregg v. Georgia (428 U.S. 153) in 1976, death penalty executions require mandatory appellate review. Thirty-five states provide for direct appeal of a capital conviction to the state court of last resort (aka, supreme courts), while Alabama and Tennessee provide for direct appeal to their intermediate courts of appeal, which may be subsequently appealed to their supreme courts. Ohio used this procedure until 1995 but changed to direct appeals to their court of last resort since then (Latzer \& Cauthen, 2007: p. 11). These cases are serious and long and because of this, we expect supreme courts operating in these states 
will be less efficient as they shoulder the burden of death penalty litigation.

We consider three additional variables operating in the broader political and social environments of supreme courts to influence their efficiency. GOVERNMENT IDEOLOGY captures the relative liberalism of the non-judicial state government. We expect as government liberalism goes up, the need for court intervention goes down. Conversely, in states where the government is conservative, criminal laws will be more punitive, the private sector will be less regulated, and government functions will be performed more spartanly. In all instances, less is addressed by government and as a result, more issues can find their way into the judicial system, providing more need for state supreme courts to operate efficiently. Because past studies have mapped the ongoing growth in criminal cases in state supreme courts over time, we include CRIMES PER CAPITA(t-1) to examine how crime differentials among states relate to the efficiency of their state supreme courts. Higher levels of crime could encourage state supreme courts to operate more efficiently, but we must keep in mind we are dealing with an appellate and not a trial court. Criminal appeals seek to reverse convictions and in states that are overwhelmed by crime this could provide a strong disincentive to process criminal appeals by state supreme courts. Finally, we include STATE POPULATION to control for the effects of large population differences on supreme court efficiency.

\subsection{Tobit Analysis Findings}

Table 2 presents the results of this analysis. The model performs remarkably well with a pseudo R2 of 0.68 and all of the variables in the model significant at or below the 0.1 level. Two substantive results can be directly interpreted from the ELECTIVE COURT and DEATH PENALTY dichotomous measures. The model indicates that ELECTIVE COURT is 12.8 percent less efficient than appointive courts, a relationship significant at the 0.05 level. State supreme courts in DEATH PENALTY states were 13.7 percent less efficient than those where the death penalty was not used, but this result is significant at only the 0.1 level.

To evaluate the comparative substantive impact of our remaining continuous independent variables, these are expressed as elasticities in Table 3. As such, they indicate the change in efficiency estimated to result from a one percent change in the level of these independent variables. Substantively, the independent variable with the largest impact is LAWYERS PER CAPITA(t-1): a one percent increase in this variable is associated with a 0.39 percent drop in efficiency, a relationship significant at the 0.01 level. Stated another way, when legal resources decrease by one percent, state supreme courts have to operate roughly 0.4 percent more efficiently. QTY DEF WINS(t-1) and CRIME PER CAPITA(t-1) exert comparable but opposite effects on court efficiency: when defendants win one percent more cases, court efficiency increases 0.35 percent; when CRIMES PER CAPITA(t-1) goes up one percent, court efficiency goes down 0.34 percent. The PAJID RANGE variable is significant at the 0.01 level: for a one percent increase in the range of ideologies on state supreme courts, 
Table 2. Tobit model of state supreme court efficiency.

\begin{tabular}{|c|c|c|c|}
\hline Variable & Coefficient & St. Error & $\mathbf{t}$ \\
\hline Elective Court & -0.128 & 0.073 & $-1.75^{\star *}$ \\
\hline Pajid Range & 0.004 & 0.002 & $2.53^{* * *}$ \\
\hline Qty Def Wins(t-1) & 0.021 & 0.004 & $4.78^{* * *}$ \\
\hline Case Filings $(t-1)$ & 0.000 & 0.000 & $1.35^{*}$ \\
\hline Lawyers Per Capita & -0.109 & 0.033 & $-3.29^{* * *}$ \\
\hline Death Penalty & -0.137 & 0.087 & $-1.57^{*}$ \\
\hline Government Ideology & -0.003 & 0.002 & $-1.41^{\star}$ \\
\hline Crimes Per Capita(t-1) & -0.005 & 0.003 & $-2.03^{\star \star}$ \\
\hline State Population & 0.000 & 0.000 & $-2.07^{\star *}$ \\
\hline Constant & 1.224 & 0.161 & $7.61^{* * *}$ \\
\hline /sigma & 0.217 & 0.033 & \\
\hline F-test $(9,39)$ & $7.260^{\star * *}$ & & \\
\hline Pseudo R2 & 0.684 & & \\
\hline No. of Observations & 48 & & \\
\hline No. of Uncensored Observations & 32 & & \\
\hline No. of Right Censored Observations & 15 & & \\
\hline No. of Left Centered Observations & 1 & & \\
\hline
\end{tabular}

${ }^{*} p \leq .10,{ }^{* *} p \leq .05,{ }^{* *} p \leq .01$, one-tailed test of significance.

Table 3. Elasticities for tobit model results.

\begin{tabular}{cc}
\hline Variable & Prediction (ey/ex) \\
\hline Elective Court & -0.128 \\
Pajid Range & 0.219 \\
Qty Def Wins(t-1) & 0.346 \\
Case Filings(t-1) & 0.149 \\
Lawyers Per Capita & -0.388 \\
Death Penalty & -0.137 \\
Government Ideology & -0.147 \\
Crimes Per Capita(t-1) & -0.344 \\
State Population & -0.205 \\
\hline
\end{tabular}

court efficiency increases 0.22 percent. GOVERNMENT IDEOLOGY is signed as expected but is only significant at the 0.1 level. Substantively its effects are comparatively mild: a one percent decrease in government liberalism increases court efficiency by only 0.15 percent. Finally, two of the variables that might be construed to capture the overall demands on state supreme courts are among the weakest variables in our analysis. CASE FILLINGS(t-1) is significant at only the 0.1 level; however, a one percent increase improves court efficiency only 0.15 
percent. STATE POPULATION is significant at the 0.05 level: a one percent difference in population is estimated to translate into a 0.21 percent decrease in court efficiency.

\section{Conclusion}

The manner in which state supreme courts produce cases exhibits remarkable diversity. Overall court efficiency reflects a confluence of institutional, legal, political and social factors. It is driven by the availability of legal representation in their state, and the pressures created by their need to overturn lower court decisions and crime levels within their states. It is further conditioned by how judges are selected, the diversity of ideologies on the court, the additional demands created by the death penalty and further conditioned by the size of their population, the ideology of their state government and the number of cases filed within their state. In addition, these courts exhibited pronounced differences in the relative efficiency in which they produced cases in the separate areas of law. Comparatively speaking, some state supreme courts do less with more, while others operate at the observed limits of their resources.

In a tradition going back to Kagan et al., it is conventional to examine the case outputs of state supreme courts as their "business". Extending this analogy, we have applied the tools of productivity analysis to scrutinize their business and it is quite evident that while these bodies perform equivalent functions across the states, they do so quite differently. Looking at overall output of courts collectively masks how different courts contribute to that total output. This analysis reveals that within the collective case output of courts, some courts are producing cases at their productive limits, while others could produce substantially more cases with their allocated resources. This is true within specific areas of law as well. Ultimately, the business of state supreme courts involves not only their production of cases, but also their capacity to produce cases and the extent to which it is engaged.

\section{Conflicts of Interest}

The authors declare no conflicts of interest regarding the publication of this paper.

\section{References}

Aigner, D., \& Chu, S. (1968). On Estimating the Industry Production Function. The American Economic Review, 58, 826-839.

Berry, W., Ringquist, E., Fording, R., \& Hanson, R. (1998). Measuring Citizen and Government Ideology in the American States, 1960-1993. American Journal of Political Science, 42, 327-348. https://doi.org/10.2307/2991759

Brace, P., \& Hall, M. G. (2001). "Haves" Versus "Have Nots” in State Supreme Courts: Allocating Docket Space and Wins in Power Asymmetric Cases. Law \& Society Review, 35, 393-417. https://doi.org/10.2307/3185407

Brace, P., Langer, L., \& Hall, M. G. (2000). Measuring the Preferences of State Supreme 
Court Judges. Journal of Politics, 62, 387-413. https://doi.org/10.2307/3185407

Brace, P., Yates, J., \& Boyea, B. (2012). Judges, Litigants, and the Design of Courts. Law \& Society Review, 46, 497-522. https://doi.org/10.1111/j.1540-5893.2012.00504.X

Brown, A. (2018). The Role of Constitutional Features in Judicial Review. State Politics \& Policy Quarterly, 18, 351-370. https://doi.org/10.1177/1532440018786732

Daniels, S. (2006). Ladders and Bushes: The Problem of Caseloads and Studying Court Activities over Time. Law and Social Inquiry, 9, 751-795.

Dinan, J. (2018). State Constitutional Politics: Governing by Amendment in the American States. Chicago, IL: University of Chicago Press. https://doi.org/10.7208/chicago/9780226532950.001.0001

Habel, P., \& Scott, K. (2014). New Measures of Judges' Caseload for the Federal District Courts, 1964-2012. Journal of Law and Courts, 2, 153-170. https://doi.org/10.1086/670669

Hammons, C. (1999). Was James Madison Wrong? Rethinking the American Preference for Short, Framework-Oriented Constitutions. American Political Science Review, 93, 837-849. https://doi.org/10.2307/2586116

Kagan, R., Cartwright, B., Friedman, L., \& Wheeler, S. (1977). The Business of State Supreme Courts, 1870-1970. Stanford Law Review, 30, 121-156.

https://doi.org/10.2307/1228176

Kritzer, H., Brace, P., Hall, M. G., \& Boyea B. (2007). The Business of State Supreme Courts, Revisited. The Journal of Empirical Legal Studies, 4, 427-439. https://doi.org/10.1111/j.1740-1461.2007.00094.x

Latzer, B., \& Cauthen, J. (2007). Justice Delayed? Time Consumption in Capital Appeals: A Multistate Study: A Multistate Study. Nation Criminal Justice Reference Service. https://www.ncjrs.gov/App/Publications/abstract.aspx?ID=239209

McIntosh, W. (1980-1981). 150 Years of Litigation and Dispute Settlement: A Court Tale. Law \& Society Review, 15, 823-848. https://doi.org/10.2307/3053513

Munger, F. (1990). Trial Courts and Social Change: The Evolution of a Field of Study. Law \& Society Review, 14, 217-226.

Pacelle, R. (1991). The Transformation of the Supreme Court's Agenda: From the New Deal to the Reagan Administration. Boulder, CO: Westview Press.

Pacelle, R. (1995). The Dynamics and Determinants of Agenda Change in the Rehnquist Court. In E. Lee (Ed.), Contemplating Courts. Washington DC: CQ Press.

Squire, P. (2008). Measuring the Professionalization of U.S. State Courts of Last Resort. State Politics \& Policy Quarterly, 8, 223-238. https://doi.org/10.1177/153244000800800301

Stookey, J. A. (1990). Trials and Tribulations: Crises, Litigation, and Legal Change. Law \& Society Review, 24, 497-520. https://doi.org/10.2307/3053692

Varian, H. (1984). The Nonparametric Approach to Production Analysis. Econometrica, 52, 579-597. https://doi.org/10.2307/1913466 
Appendix A. Variable definitions and descriptive statistics.

\begin{tabular}{|c|c|c|}
\hline Variable & Mean & St. Deviation \\
\hline \multicolumn{3}{|l|}{ Output Variables } \\
\hline Criminal Litigation Output: Mean number of criminal cases decided by court (SSCDA) & 44.10 & 22.02 \\
\hline Tort Litigation Output: Mean number of tort cases decided by court (SSCDA) & 31.10 & 13.33 \\
\hline Public Law Litigation Output: Mean number of public law cases decided by court (SSCDA) & 42.34 & 18.75 \\
\hline \multicolumn{3}{|l|}{ Input Variables } \\
\hline Constitutional Policy Content: Number of policy provisions in state constitution (Hammons, 1999) & 790.81 & 726.15 \\
\hline Size of Court: Number of seats on court (American Judicature Society) & 6.42 & 1.23 \\
\hline Lower Appellate Court: 1 if state has lower appellate court, 0 otherwise (American Judicature Society) & 0.77 & 0.42 \\
\hline \multicolumn{3}{|l|}{ Tobit Model Variables } \\
\hline Overall Efficiency: Measure of relative efficiency for production of all cases & 0.77 & 0.22 \\
\hline Elective Court: 1 if state uses judicial elections; 0 otherwise (American Judicature Society) & 0.75 & 0.44 \\
\hline Pajid Range: Mean distance between the most conservative and liberal ideology (Brace, Langer, \& Hall, 2000) & 42.95 & 17.36 \\
\hline Qty Def Wins(t-1): Lagged measure of defendant success in state supreme courts (SSCDA) & 13.56 & 6.95 \\
\hline Case Filings $(\mathrm{t}-1)$ : Lagged measure of total case filings in state court system (National Center for State Courts) & 1523.31 & 1318.68 \\
\hline Lawyers Per Capita: Number of state attorneys adjusted to state population (1990 U.S. Census) & 2.64 & 0.90 \\
\hline Death Penalty: 1 if state has enacted the death penalty; 0 otherwise (Death Penalty Information Center) & 0.75 & 0.44 \\
\hline Crimes Per Capita(t-1): Lagged crime index adjusted to state population (U.S. Federal Bureau of Investigation) & 48.10 & 12.34 \\
\hline State Population: Number of state residents divided by 1000 (1990 U.S. Census) & 4751.09 & 5286.07 \\
\hline
\end{tabular}

